\title{
The focus of marketing communication efforts of smes within south Africa
}

\author{
Safura Mohamed KALLIER \\ University of South Africa, Pretoria, South Africa \\ Kallism@unisa.ac.za
}

\begin{abstract}
Marketing communication is seen as a vital activity for the survival and success of SMEs. Traditionally tools such as pamphlets, local newspapers, posters and business cards were primarily used to promote SMEs. Today, however, the communication landscape has evolved due to technological advancements. As a result, there are many more communication tools that can be used by SMEs to conduct marketing communication activities of the business. The focus of this study is thus to determine the usage of traditional and technology-enabled marketing communication tools employed by SMEs in South Africa. A self-administered questionnaire was used to collect data from SMEs in South Africa. The results of this study indicate that most SMEs make use of e-media such as websites and e-mails as marketing communication tools. This article provides insight into the marketing communication tools that are being used by SMEs in South Africa which will contribute to the understanding of SMEs marketing practices. Studies suggest that there are many similarities regarding the challenges faced by SMEs globally and as such the findings of this study can be applied universally.
\end{abstract}

Keywords: Marketing, communication, SMEs, traditional marketing, technology-enabled marketing.

Please cite the article as follows: Kallier, S.M. (2017), "The focus on marketing communication efforts of SMEs", Management \& Marketing. Challenges for the Knowledge Society, Vol. 12, No. 1, pp. 140-154, DOI: 10.1515/mmcks-2017-0009.

\section{Introduction}

SMEs are an important aspect of the economy locally and internationally and marketing communication within SMEs is an important activity for the success of the business (Resnick et al., 2016). Marketing communications refers to the process through which a business communicates with its target audience through different communication methods (American Marketing Association, 2013). The aim of marketing communication activities is to inform consumers about the business and the products they offer, to persuade consumers to make purchases and to remind consumers about the business (Pride et al., 2015). The marketing communication function is thus important to SMEs as without marketing communication, the customer would not know about the business or the products that it sells (Popescu et al., 2013).

Traditionally, marketing communications such as pamphlets, business cards, posters and local newspapers were used by businesses to communicate with their customers. With the rapid advancements in technology, and the development of the internet and new communication methods, the way in which people communicate with each other has changed (Salehi et al., 2012). As a result of the many new communication methods available, the way in which business is done and the way in which businesses communicate with their customers have changed as well (Salehi et 
al., 2012). These new marketing communication methods have various benefits for SMEs such as enhancement of exposure for the business, cost effectiveness, the ability to reach new customers and the ability to be more competitive (Taiminen and Karjaluoto, 2015). Even though technology-enabled marketing communications provides many benefits to SMEs, many SMEs are still making use of traditional marketing communication tools (Cant and Wiid, 2016). This study thus aims to determine whether SMEs in South Africa are focusing their marketing communication efforts on traditional or technology-enabled marketing communication media. The study will make a significant contribution in understanding the marketing communication tools (traditional or technology-enabled) used by SMEs in South Africa. This understanding of the marketing communication tools used by SMEs can provide additional knowledge of how SMEs in South Africa operate and what makes them succeed or fail.

The following section will provide a brief background on SMEs in South Africa, followed by a discussion on traditional and technology-enabled marketing communications. Finally, the research objectives are outlined, followed by the methodology, the results, conclusions and recommendations of the study.

\section{Literature review}

\section{Small and medium enterprises (SMEs) in South Africa}

The definition of small and medium enterprises (SMEs) vary in different countries and is usually derived based on the economy and government policies and regulations of the country. A small business in developed countries such as the United States of America and the United Kingdom may be a large scale business in a developing country. In South Africa, SMEs are defined by the National Small Business Act 102 of 1996 as "a separate and distinct business entity, including cooperative enterprises and non-governmental organisations, managed by one owner or more, which, including its branches or subsidiaries, if any, is predominantly carried on in any sector or subsector of the economy" (National Small Business Act, 1996). The act further identifies four types of business based on the size of the business, the annual turnover, the number of employees and the gross asset value (National Small Business Act, 1996).

SMEs are said to be essential to an economy as they drive sustainable growth, contribute to job creation, and the alleviation of poverty, this being especially true for developing countries (Smit and Watkins, 2012). SMEs also contribute to the generation of revenue and innovation and technological advancements of a country (Asah et al., 2015). SMEs contribute to about 99\% of enterprises in the European Union and there are an estimated 21 million SMEs that provide up to 33 million jobs in the European Union (Fact sheet on the European Union, 2016). In developing countries, SMEs contribute largely to the employment rate and the gross domestic income of the country (World Bank, 2015). In Nigeria, more than $90 \%$ of enterprises are SMEs which contribute $10 \%$ to the country's GDP (Ghandi and Amissah, 2014).

In South Africa it is estimated that SMEs make up about 91\% of the formalised business sector and contribute to approximately 34\% of the country's GDP (The Banking Association of South Africa, 2016). It is also estimated that SMEs contribute to about 61\% of job creation in South Africa (Mavimbela and Dube, 2016). In South 
Africa, SMEs contribute positively to social stability within the country, the prosperity in rural areas, and they enhance the population's general level of economic participation (Asah et al., 2015). Even though SMEs play such an important role in the country and its economy, there is a high failure rate. It is estimated that close to $75 \%$ of SMEs fail within their first two years of existence (Hendricks et al., 2015). This failure rate can be attributed to factors such as lack of skills, lack of resources, lack of finance, lack of access to technology and lack of marketing skills (Van Scheers, 2010). This high failure rate could also be a contributing factor to determining which marketing communication media will be used by SMEs (Cant and Wiid, 2016).

\section{SMEs and marketing communication}

Among the various elements that contribute to the success of an SME is the ability of the business to provide the market with information about the business, the product that they sell, the quality, and the attributes and benefits of the product. Marketing communication delivers value for customers by providing them with reasons to purchase a product from a business, thus creating growth for the business (Cacciolatti and Fearne, 2013). Even though marketing is seen as an important element for the success of the SME, previous research has indicated that there is a lack of marketing communication and marketing skills within SMEs (Franco et al., 2014). Studies indicate there is often a lack of marketing expertise, a lack of financial resources to implement marketing communication activities, and a lack of information regarding marketing communication (Mpofu and Chigwende, 2013). SMEs also have to compete with larger organisations that have much more resources at their disposal to market their businesses (Hassan et al., 2015).

Marketing communication efforts within SMEs are largely influenced by the environment in which the business operates the skills and resources of the business, and the characteristics of the owner (Franco et al, 2014). Decisions within SMEs are usually made by the owner and, as such, decisions regarding marketing are implemented based on the owner's intuition (Seyyedamiri and Faghih, 2015). As such the marketing communication activities of SMEs are more informal and are done in reaction to environmental conditions (Seyyedamiri and Faghih, 2015).

\section{Traditional and technology-enabled marketing communication}

Traditionally, organisations made use of marketing communication print media such as pamphlets, posters, local newspapers and business cards to promote their businesses. These marketing communication tools allowed the business to communicate its product offering to the consumer and gain exposure for the business. The major development in technology has, however, led to various technologyenabled marketing communication tools that businesses can utilise to communicate and interact with their customers (Koekemoer, 2014). These technology-enabled marketing tools include social media such as Facebook and Twitter, mobile media such as short message services (SMS), multimedia messaging services (MMS) and voice messages, and websites, blogs and e-mail.

Social media refers to a group of websites or applications that allow individuals to engage with each other, create and share content, and partake in social networking activities (Kim, 2016). There are various social media platforms available 
such as Facebook and Twitter. These platforms allow businesses to interact with their customers directly, involve much lower costs, and allow businesses to monitor what is being said about their business (Hassan et al., 2015).

Mobile media refers to the promotional tool that makes use of mobile devices such as cell phones, mobile tablets or other hand-held devices to deliver marketing communication messages to consumers (Heart, 2014). The tools used for mobile media include SMS, MMS, and voice messages. These mobile media tools allow for marketing communication messages to be sent directly to individual consumers (Amirkhanpour et al., 2014).

E-media refers to electronic media such as websites, e-mails and blogs that are used as marketing communication tools. Websites refer to a collection of web pages containing relevant content that is made available through the internet (BusinessDictionary.com, 2016). The business can make use of websites to provide customers with information about the business, to promote products, provide information on the various products, indicate the location of the business, and how to contact them (Marketingdonut.com, 2016).

E-mails, which refer to electronic mail that is sent over the internet, are also used as a marketing tool when businesses send promotional messages to individual consumers via e-mail. Blogs, which refers to web logs, are web pages used by individuals to express themselves and that are frequently updated by the user (Blogbasics.com, 2016). Businesses can make use of blogs to introduce their company, to educate the target market about the company and its products, and to create an identity for the company (Hammis, 2015).

Compared to traditional marketing efforts, technology-enabled marketing communication is more cost-efficient, making it a much more viable option for SMEs (Patil and Bhakkad, 2014). Technology-enabled marketing communication is immediate and easy to track compared to traditional marketing communication tools where various drafts need to be formulated before it can be approved for print or television media (Nobre and Silva, 2014). Technology-enabled marketing also provides business with instant feedback compared to traditional media (Ahmed and Hussain 2014). Many businesses have recognised the many benefits of technologyenabled marketing communication tools and their ability to promote their business. Research by Eid and El-Gohary (2013) found that, if used correctly, the use of electronic marketing tools (technology-enabled marketing tools) can lead to positive results in terms of improved marketing performance and effectiveness.

While there is an increase in the use of technology-enabled marketing communication tools, many SMEs still make use of traditional marketing communication tools (Ahmed and Hussain 2014). A study by Cant and Wiid (2016) indicated that more than $20 \%$ of the SME respondents who participated in the study made use of traditional marketing communication tools. The results of their study also indicated that respondents found traditional marketing communication tools to be "effective or very effective" (Cant and Wiid, 2016:). Lekhanya (2015) found that although SMEs find benefits of using technology-enabled marketing communication, such as increased reach of customers, their use of technology-enabled marketing communications is limited by lack of communication services and lack of finance. 
In further understanding how SMEs conduct their marketing activities, this study focused on determining whether or not South African SMEs are focusing their marketing efforts on traditional or technology-enabled marketing. This study will contribute to the understanding of SMEs marketing practices.

\section{Research objectives}

The focus of this article is to determine whether South African SMEs are focusing their marketing efforts on traditional or technology-enabled marketing. The objective of the study is thus: to determine whether South African SMEs are focusing their marketing communication efforts on traditional or technology-enabled marketing communication media.

\section{Methodology}

Data collection was done via electronic distribution of a self-administered questionnaire consisting of quantitative questions to a sample of SME owners operating in the coastal regions of the Western Cape and Kwazulu-Natal, and who registered their small businesses at an official state institution for SMEs. The sampling methodology utilised was that of non-probability, convenience sampling, which enabled the researcher to collect data quickly and easily. A sufficient number of questionnaires were distributed to achieve a confidence level of $95 \%$ and an error margin of $5 \%$ at $50 \%$ response distribution. A total of 123 usable responses were received, which represented an error margin of $8.14 \%$. The online Raosoft sample size calculator was used to calculate the sample (Raosoft, 2016). Given the small sample size, the results will give a general indication on whether SMEs are focusing their marketing efforts on traditional or technology-enabled marketing.

The quantitative data was analysed using SAS. The data was checked, coded, corrected and descriptive statistics (frequency counts) were used to describe the findings. Varimax rotation was conducted to assess the underlying structure and the Cronbach alpha measure was performed to determine consistency of the measurement.

The respondent group consisted of owners (45.45\%), managers (18.18\%), and owner manager (36.36\%). The majority $(58.46 \%)$ of these businesses have been in operation for less than five years, whereas a small percentage (4.46\%) has been in existence for more than 25 years. The majority $(58,62 \%)$ of the respondents are female and more than half (56.9\%) of the respondents were older than 40 years. Almost two thirds $(62,12 \%)$ of the respondents had a post-school qualification ranging from certificates to post-graduate degrees. An overview of the main findings is provided in the next section.

\section{Results}

The small business owners were presented with a list of fourteen marketing communication tools that they could use to communicate to their customers. They were asked to indicate the usage of the different communication tools on a five-point scale ranging from "not at all" to "always". Table 1 is indicative of the results obtained for this question. It is clear from the table that the majority of respondents always use business cards $(64,1 \%)$, websites $(57,1 \%)$ and e-mails $(64,6 \%)$. The majority of the 
respondents do not use MMS $(52,7 \%)$, voice messages $(52,2 \%)$ or blogs $(55,1 \%)$. Table 1 indicates the distribution of responses for the usage of various marketing communication tools.

Table 1. Distribution of response for the usage of various marketing communication tools

\begin{tabular}{|c|c|c|c|c|c|c|c|}
\hline $\begin{array}{l}\text { Question } \\
\text { No. }\end{array}$ & Marketing Tools & Not at all & Rarely & Sometimes & Often & Always & $\begin{array}{l}\text { Total } \\
\text { Responses } \\
\text { (n) }\end{array}$ \\
\hline Q1.1 & Pamphlets & $\begin{array}{l}21 \\
18.8 \%\end{array}$ & $\begin{array}{l}12 \\
10.7 \%\end{array}$ & $\begin{array}{l}30 \\
26.8 \%\end{array}$ & $\begin{array}{l}16 \\
14.3 \%\end{array}$ & $\begin{array}{l}33 \\
29.5 \%\end{array}$ & 112 \\
\hline Q1.2 & Business cards & $\begin{array}{l}7 \\
6.0 \%\end{array}$ & $\begin{array}{l}2 \\
1.7 \%\end{array}$ & $\begin{array}{l}12 \\
10.3 \%\end{array}$ & $\begin{array}{l}21 \\
17.9 \%\end{array}$ & $\begin{array}{l}75 \\
64.1 \%\end{array}$ & 117 \\
\hline Q1.3 & Poster & $\begin{array}{l}34 \\
30.9 \% \\
\end{array}$ & $\begin{array}{l}14 \\
12.7 \% \\
\end{array}$ & $\begin{array}{l}19 \\
17.3 \% \\
\end{array}$ & $\begin{array}{l}16 \\
14.5 \% \\
\end{array}$ & $\begin{array}{l}27 \\
24.5 \% \\
\end{array}$ & 110 \\
\hline Q1.4 & Local newspapers & $\begin{array}{l}53 \\
47.3 \%\end{array}$ & $\begin{array}{l}15 \\
13.4 \%\end{array}$ & $\begin{array}{l}19 \\
17.0 \%\end{array}$ & $\begin{array}{l}7 \\
6.3 \%\end{array}$ & $\begin{array}{l}18 \\
16.1 \%\end{array}$ & 112 \\
\hline Q1.5 & Social media & $\begin{array}{l}14 \\
18.7 \% \\
\end{array}$ & $\begin{array}{l}3 \\
4.0 \% \\
\end{array}$ & $\begin{array}{l}16 \\
21.3 \% \\
\end{array}$ & $\begin{array}{l}8 \\
10.7 \% \\
\end{array}$ & $\begin{array}{l}34 \\
45.3 \% \\
\end{array}$ & 75 \\
\hline Q1.6 & Facebook & $\begin{array}{l}26 \\
23.0 \%\end{array}$ & $\begin{array}{l}7 \\
6.2 \%\end{array}$ & $\begin{array}{l}16 \\
14.2 \%\end{array}$ & $\begin{array}{l}19 \\
16.8 \%\end{array}$ & $\begin{array}{l}45 \\
39.8 \%\end{array}$ & 113 \\
\hline Q1.7 & Twitter & $\begin{array}{l}39 \\
39.4 \% \\
\end{array}$ & $\begin{array}{l}7 \\
7.1 \% \\
\end{array}$ & $\begin{array}{l}10 \\
10.1 \% \\
\end{array}$ & $\begin{array}{l}15 \\
15.2 \% \\
\end{array}$ & $\begin{array}{l}28 \\
28.3 \% \\
\end{array}$ & 99 \\
\hline Q1.8 & Mobile media & $\begin{array}{l}19 \\
34.5 \% \\
\end{array}$ & $\begin{array}{l}3 \\
5.5 \% \\
\end{array}$ & $\begin{array}{l}10 \\
18.2 \% \\
\end{array}$ & $\begin{array}{l}6 \\
10.9 \% \\
\end{array}$ & $\begin{array}{l}17 \\
30.9 \% \\
\end{array}$ & 55 \\
\hline Q1.9 & SMS & $\begin{array}{l}31 \\
31.0 \% \\
\end{array}$ & $\begin{array}{l}11 \\
11.0 \% \\
\end{array}$ & $\begin{array}{l}18 \\
18.0 \% \\
\end{array}$ & $\begin{array}{l}12 \\
12.0 \% \\
\end{array}$ & $\begin{array}{l}28 \\
28.0 \% \\
\end{array}$ & 100 \\
\hline Q1.10 & MMS & $\begin{array}{l}48 \\
52.7 \% \\
\end{array}$ & $\begin{array}{l}12 \\
13.2 \% \\
\end{array}$ & $\begin{array}{l}8 \\
8.8 \%\end{array}$ & $\begin{array}{l}5 \\
5.5 \% \\
\end{array}$ & $\begin{array}{l}18 \\
19.8 \% \\
\end{array}$ & 91 \\
\hline Q1.11 & Voice message & $\begin{array}{l}48 \\
52.2 \%\end{array}$ & $\begin{array}{l}14 \\
15.2 \% \\
\end{array}$ & $\begin{array}{l}10 \\
10.9 \%\end{array}$ & $\begin{array}{l}5 \\
5.4 \% \\
\end{array}$ & $\begin{array}{l}15 \\
16.3 \% \\
\end{array}$ & 92 \\
\hline
\end{tabular}

Vol.12, No.1, Spring, pp. 140-154, ISSN 1842-0206 | Management \& Marketing. Challenges for the Knowledge Society 


\begin{tabular}{|c|c|c|c|c|c|c|c|}
\hline Q1.12 & Website & $\begin{array}{l}20 \\
17.9 \%\end{array}$ & $\begin{array}{l}3 \\
2.7 \%\end{array}$ & $\begin{array}{l}9 \\
8.0 \%\end{array}$ & $\begin{array}{l}16 \\
14.3 \%\end{array}$ & $\begin{array}{l}64 \\
57.1 \%\end{array}$ & 112 \\
\hline Q1.13 & Blogs & $\begin{array}{l}54 \\
55.1 \% \\
\end{array}$ & $\begin{array}{l}10 \\
10.2 \%\end{array}$ & $\begin{array}{l}5 \\
5.1 \% \\
\end{array}$ & $\begin{array}{l}13 \\
13.3 \% \\
\end{array}$ & $\begin{array}{l}16 \\
16.3 \% \\
\end{array}$ & 98 \\
\hline Q1.14 & E-mail & $\mid \begin{array}{l}10 \\
8.8 \%\end{array}$ & $\begin{array}{l}6 \\
5.3 \%\end{array}$ & $\begin{array}{l}16 \\
14.2 \%\end{array}$ & $\begin{array}{l}8 \\
7.1 \%\end{array}$ & $\begin{array}{l}73 \\
64.6 \%\end{array}$ & 113 \\
\hline
\end{tabular}

Source: Authors' own research.

\section{Construct validity of traditional or technology-enabled marketing} communication tools

To examine the construct validity of the measures adopted in this study, a factor analysis was performed. Maximum likelihood extraction with varimax rotation was conducted to assess the underlying structure for the fourteen items. Three factors were requested, based on the screen plot, eigenvalues and \% of variance, as well as the minimum of three items per construct.

After rotation, the first factor accounted for $22.36 \%$ of the variance, the second factor accounted for $20.14 \%$, the third factor accounted for $12.42 \%$, and the fourth factor $9.81 \%$. Table 2 displays the items and factor loadings for the rotated factors.

Table 2. Rotated factor loading for the rotated factors

\begin{tabular}{|l|l|l|l|l|}
\hline & Factor 1 & Factor 2 & Factor 3 & Factor 4 \\
\hline Pamphlets & 0.05 & -0.1 & 0.71 & 0.18 \\
\hline Business cards & 0.03 & 0.05 & 0.29 & 0.38 \\
\hline Poster & 0.19 & 0.25 & 0.72 & 0.11 \\
\hline Local newspapers & 0.43 & 0.25 & 0.62 & 0.12 \\
\hline Social media & 0.19 & 0.83 & 0.23 & 0.17 \\
\hline Facebook & -0.0 & 0.93 & 0.02 & 0.06 \\
\hline Twitter & 0.12 & 0.78 & 0.03 & 0.18 \\
\hline Mobile media & 0.82 & 0.32 & 0.27 & -0.0 \\
\hline SMS & 0.84 & 0.01 & 0.03 & 0.11 \\
\hline MMS & 0.89 & 0.10 & 0.08 & 0.23 \\
\hline Voice message & 0.73 & 0.06 & 0.16 & 0.04 \\
\hline Website & 0.08 & 0.34 & 0.21 & 0.49 \\
\hline Blogs & 0.35 & 0.50 & 0.17 & 0.24 \\
\hline E-mail & 0.18 & 0.19 & 0.06 & 0.86 \\
\hline & & & & \\
\hline \% of variance explained & 22.36 & 20.14 & 12.42 & 9.81 \\
\hline \% of cumulative variance explained & 22.36 & 42.50 & 54.92 & 64.73 \\
\hline
\end{tabular}

Maximum likelihood extraction was used with varimax rotation and Kaiser normalisation, $\mathrm{N}=123$. Factor $1=$ Mobile media; Factor $2=$ Social media; Factor $3=$ Traditional print media; Factor 4 = E-media

Most factor loadings were 0.4 or above, showing good convergent validity (Feinberg et al., 2013). The constructs are therefore unidimensional and factorially Vol. 12, No.1, Spring, pp. 140-154, ISSN 1842-0206 | Management \& Marketing. Challenges for the Knowledge Society 
distinct, and all items used to operationalise a construct load onto a single factor. Some cross loadings were experienced, while there were also a lot of items that didn't load anywhere.

\section{Measures}

Reliability is the consistency of the measurement, or the degree to which an instrument measures the same way each time it is used, under the same condition with the same subjects. A Cronbach's alpha value above 0.8 has a good reliability, a value between 0.6 and 0.8 has an acceptable reliability and a value below 0.6 has an unacceptable reliability. Hair, Anderson, Tatham and Black (1998) recommended that Cronbach alpha values from 0.6 to 0.7 were deemed the lower limit of acceptability. Table 3 indicates the Cronbach's Alpha values.

Table 3. Cronbach's alpha values

\begin{tabular}{|l|l|l|}
\hline Construct/Scale & Items & Cronbach's alpha \\
\hline Mobile media & $1.8 ; 1.9 ; 1.10 ; 1.11$ & 0.89 \\
\hline Social media & $1.5 ; 1.6 ; 7 ; 1.13$ & 0.85 \\
\hline Traditional print media & $1.1 ; 1.3 ; 1.4$ & 0.79 \\
\hline E-media & $1.12 ; 1.14$ & 0.66 \\
\hline
\end{tabular}

Source: Authors' own research.

The Cronbach's alpha value for the 4 sub-constructs all yielded acceptable values $(>=0.60)$, which is considered very good. Hence, the results demonstrate that the questionnaire is a reliable measurement instrument.

\section{The use of traditional or technology-enabled marketing communication tools}

The score for each of the constructs (mobile media, social media, print media, and emedia) is represented by a single value after calculating the mean of the applicable items relating to the construct. Table 4 provides descriptive statistics of the respondents' mean score for these constructs.

Table 4. Mean scores of the constructs

\begin{tabular}{|l|l|}
\hline Marketing communication media & Mean \\
\hline Mobile media & 2.54 \\
\hline Social media & 3.05 \\
\hline Print media & 2.86 \\
\hline E-media & 4.03 \\
\hline
\end{tabular}

Source: Authors' own research.

It is clear from Table 4 that, according to the mean scores of the constructs, emedia (4.03) is being used the most, whereas mobile media (2.54) is being used the least.

In order to determine the use of the different marketing communication media, the highest construct scores were used to classify each respondent in the categories mobile media, social media, print media, and e-media. Where the highest construct scores were equal in two or more constructs, this was regarded as a combination. 
The different categories are presented in Figure 1. According to Figure 1, 31\% of the respondents make use of a combination of marketing communication media, while $49 \%$ of the respondents are using e-media. Figure 1 illustrates the percentage of us of the different marketing communication media.

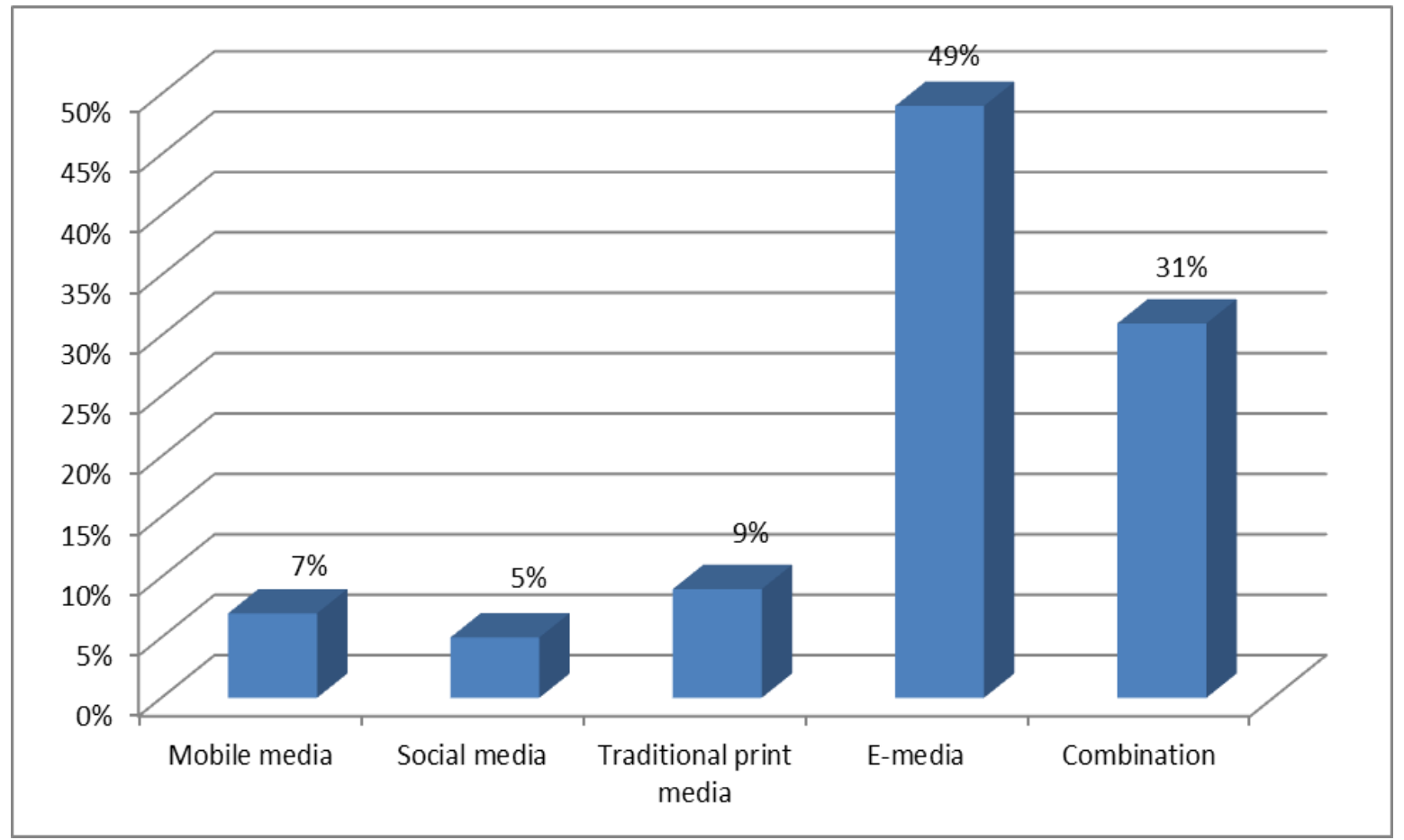

Figure 1. Use of the different marketing communication media

Source: Authors' own research.

Explore the influence of respondents' biographic profile to the constructs mobile media, social media, print media, and e-media

In order to determine and explore any influence of the biographical profile of the respondents to the various contrasts identified, the mean score per biographical element for each of the constructs was determined and compared. The biographic detail includes gender, age, position in the SME, and years in operation. No statistical tests had been done due to missing biographical values. By exploring the mean score per biographical element for each, the construct gives an indication of possible gaps in the utilisation of marketing communication media for future research. It is evident from Table 5 that possible gaps might exist on a gender basis regarding social media use; based on the age of the respondents there is the possibility of a gap regarding the use of print media. Based on the years in operation it appears there are gaps regarding social, print, and e-media. Table 5 indicates the comparison of the mean scores per biographical element (age, gender, and years in operation) for each construct. 
Table 5. Comparing the mean score per biographical element for each construct

\begin{tabular}{|c|c|c|c|}
\hline \multicolumn{4}{|l|}{ GENDER } \\
\hline & Female & Male & Difference in mean scores \\
\hline Mobile media & 2.79 & 2.37 & 0.42 \\
\hline Social media & 3.13 & 2.30 & 0.83 \\
\hline Print media & 2.63 & 3.25 & 0.62 \\
\hline E-media & 3.95 & 3.79 & 0.16 \\
\hline \multicolumn{4}{|l|}{ AGE } \\
\hline & $<30$ years & $30+$ years & Difference in mean scores \\
\hline Mobile media & 2.47 & 2.67 & 0.2 \\
\hline Social media & 3.00 & 2.71 & 0.29 \\
\hline Print media & 2.56 & 3.01 & 0.45 \\
\hline E-media & 3.62 & 3.96 & 0.34 \\
\hline \multicolumn{4}{|c|}{ YEARS IN OPERATIONS } \\
\hline & $<10$ years & $10+$ years & Difference in mean scores \\
\hline Mobile media & 2.50 & 2.15 & 0.35 \\
\hline Social media & 2.77 & 3.23 & 0.46 \\
\hline Print media & 2.75 & 3.43 & 0.68 \\
\hline E-media & 3.84 & 4.35 & 0.51 \\
\hline
\end{tabular}

Source: Authors' own research.

When exploring the influence of the position of the respondents to the constructs mobile media, social media, print media, and e-media, it appears that based on position of the respondent in the SME, that there might be gaps between the owner and manager regarding the utilisation social media and e-media. These results are seen in table 6 and figure 2. Table 6 indicates the comparison of the mean scores of the biographical element 'position' for each construct.

Table 6. Comparing the mean scores of the position of the respondents to each construct

\begin{tabular}{|l|l|l|l|l|l|l|}
\hline & Owner & Manager & Both & $\begin{array}{l}\text { Difference } \\
\text { in mean } \\
\text { scores } \\
\text { owner vs } \\
\text { manager }\end{array}$ & $\begin{array}{l}\text { Difference } \\
\text { in mean } \\
\text { scores } \\
\text { owner vs } \\
\text { both }\end{array}$ & $\begin{array}{l}\text { Difference } \\
\text { in mean } \\
\text { scores } \\
\text { manager } \\
\text { vs both }\end{array}$ \\
\hline $\begin{array}{l}\text { Mobile } \\
\text { media }\end{array}$ & 2.45 & 2.73 & 2.38 & 0.28 & 0.07 & 0.35 \\
\hline $\begin{array}{l}\text { Social } \\
\text { media }\end{array}$ & 2.97 & 2.57 & 2.91 & 0.4 & 0.06 & 0.34 \\
\hline Print media & 2.83 & 2.83 & 2.93 & 0 & 0.1 & 0.1 \\
\hline E-media & 4.14 & 3.64 & 3.84 & 0.5 & 0.3 & 0.2 \\
\hline
\end{tabular}

Source: Authors' own research.

The gap between the owner and the manager can clearly be seen in figure 2 . 


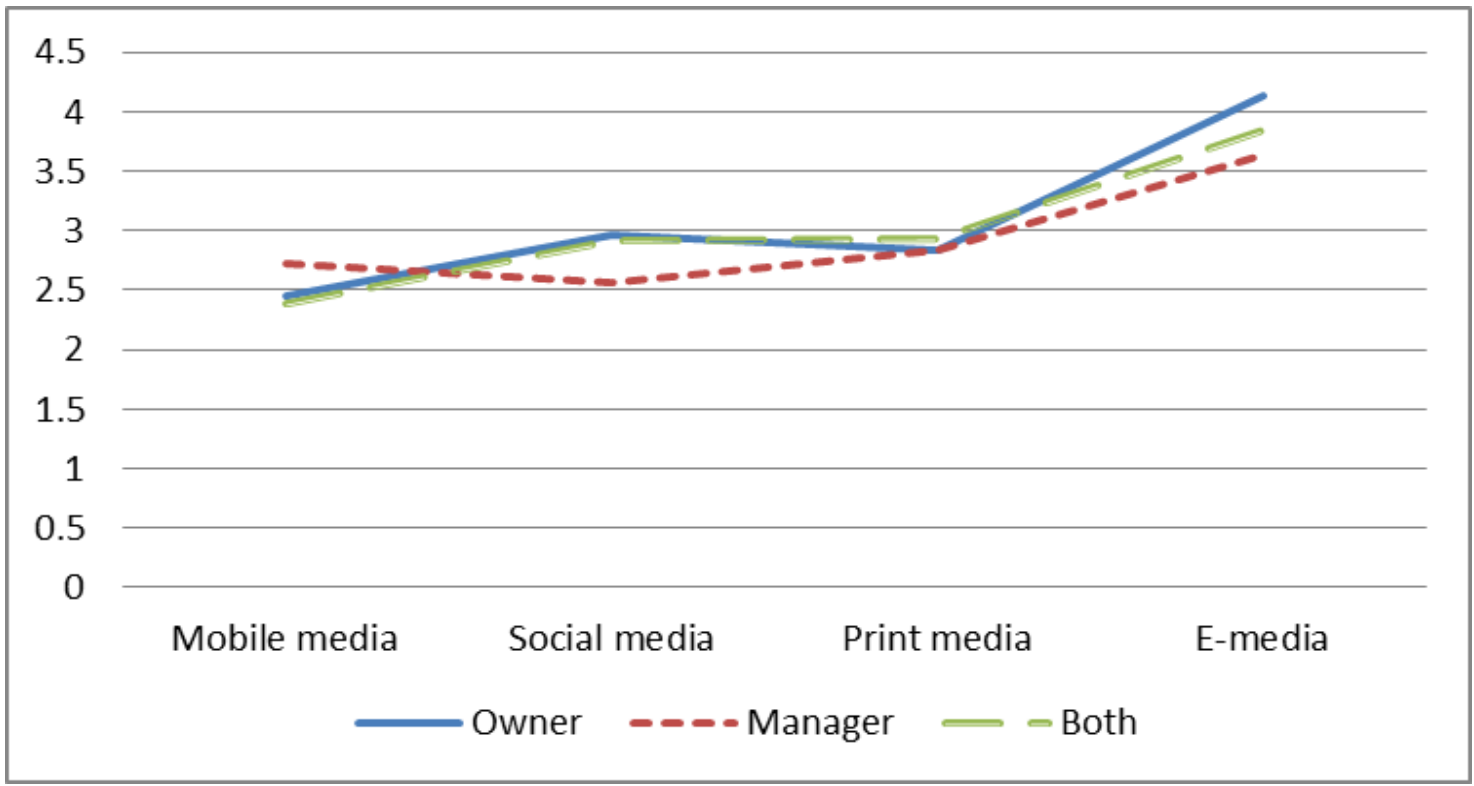

Figure 2. Possible gaps between the owner, manager and both compared to the constructs

Source: Authors' own research.

\section{Discussion}

Marketing communication consists of messages and related media used by SMEs and business to communicate with the target market. Traditionally marketing communication took place via the print media such as business cards, local newspapers, posters and pamphlets. The development of the computer and electronic environment presented SMEs and business with communication platforms such as mobile media (SMSM, MMS and voice messages), social media (Facebook and Twitter) and e-media (websites, e-mail and blogs). The objective of the study was to determine whether SMEs are focusing their marketing communication efforts on traditional or technology-enabled marketing communication media. This will provide an indication of what media SMEs prefer using when communicating with their market and will further contribute to the understanding of SMEs marketing practices.

It is clear from the study that the majority of the respondents used traditional and as well as e-media as marketing communication platforms to communicate with the market. Of the traditional communication media platforms used, business cards were the most common with $64,1 \%$ of the respondents indicating that they always used this medium, whereas e-mails were the most utilised e-media marketing communication platform with $64,6 \%$ of the respondents indicating that they always used this communication medium. Four constructs - mobile media, social media, print media and e-media - were identified by means of a factor analysis. The Cronbach's alpha for the four sub-constructs all yielded acceptable Cronbach's alpha values $(>=0.60)$, which is considered very good. Hence, the results demonstrate that the questionnaire used in the research was a reliable measurement instrument. It is 
evident from the study based on construct mean scores that e-media (4.03) was being used the most whereas mobile media (2.54) was being used the least. Almost a third (31\%) of the respondents made use of some sort of combination of traditional media, e-media and social media to communicate with the market. The different combinations used have not been tested.

The influence of the biographic profile of respondents upon the constructs (mobile media, social media, print media, and e-media) was explored and possible gaps were highlighted. The likely gaps indicate that the selection and choice of marketing communication media might be based on owners' and/or managers' personal preferences. These gaps were not statistically tested due to missing values. These gaps represent an area for further research.

\section{Recommendation and conclusion}

SME owners and managers can make use of marketing communication to drive and stimulate sales to enhance the enterprise's financial viability and continuance. Selecting the right marketing communication tools to communicate with their customers is thus important for SMEs. With the advancements in technology over the years, the marketing communication tools that can be used to communicate with consumers has increased. SMEs now have the option of making use of traditional marketing communication tools (pamphlets, posters, local newspapers and business cards) or technology-enabled marketing tools (social media such as Facebook and Twitter, mobile media and websites, blogs and e-mail) to communicate with their customers and to promote their businesses. With more options available, SMEs can identify the most cost effective method of communicating with their customers that will produce the most results.

This study aimed to determine whether South African SMEs are focusing their marketing communication efforts on traditional or technology-enabled marketing communication media. The results of the study suggests that the majority of respondents made use of e-media (websites, blogs and e-mail) to communicate with their customers, however, the enterprises need to establish which marketing communication media is suitable for the target market and which media is most used by its customers. The selection and choice of media should not be left to chance but grounded in market research. It is recommended that SME owners and/or managers research the media that is being used by the target market and then use the same in their marketing communication efforts. 


\section{References}

American Marketing Association. (2013), "Definition of marketing communication" Available at: https://www.ama.org/AboutAMA/Pages/Definition-ofMarketing.aspx (accessed June 27, 2016).

Ahmed, B. and Husain, S.T. (2014), "E-marketing - A paradigm shift in the 21st century", in Patil, D.B, Bhakkad, D.D. (eds). (2014), Redefining Management practices and marketing in modern age, Atharva publications.

Amirkhanpour, M., Vrontis, D. and Thrassou. A. (2014), "Mobile marketing: a contemporary strategic perspective", International Journal of Technology Marketing, Vol 9, No 3, pp. 252-269.

Blogbasics.com. (2016), "What are blogs?” Available at: http://blogbasics.com/whatis-a-blog/ (accessed 30 June, 2016).

BusinesnessDictionary.com. (2016), "Website" Available at: http://www.businessdictionary.com/definition/website.html (accessed 30 June).

Cacciolatti. L.A. and Fearne, A. (2013), "Marketing intelligence in SMEs: implications for the industry and policy makers", Marketing Intelligence \& Planning, Vol. 31, No. 1, pp. 4-26.

Cant, M.C. and Wiid, J.A. (2016), "The use of traditional marketing tools by SMEs in an emerging economy: a South African perspective", Problems and perspective Management, Vol. 14, No. 1, pp. 64-70.

Eid, R. and El-Gohary, H. (2013), "The impact of E-marketing use on small business enterprises' marketing success", The Service Industries Journal, Vol. 33, No. 1, pp. 31-50.

Fact Sheet on the European Union. (2016), "Small and Medium-sized enterprises", Available at: http://www.europarl.europa.eu/ftu/pdf/en/FTU_5.9.2.pdf (accessed December 14, 2016).

Feinberg, F.M., Kinner, T.C. and Taylor,R.J. (2013), Modern Marketing Research. 2nd ed. Ohio: Cengage Learning.

Franco, M., Santos, M.F., Ramalho, I. and Nunes, C. (2014), "An exploratory study of entrepreneurial marketing in SMEs", Journal of Small Business and Enterprise Development, Vol. 21, No. 2, pp. 265-283.

Hair, J.F., Anderson, R.E., Tatham, R.L. and Black, W.C. (1998), Multivariate data analysis, Upper Saddle River, NJ: Prentice Hall.

Hassan, S., Nadzim, S.Z.A. and Shiratuddin, N. (2015), "Strategic Use of Social Media for Small Business Based on the AIDA Model", Procedia - Social and Behavioural Sciences, Vol. 172, No. 27, pp. 262- 269.

Hendricks, B., Hendricks, G., Johnson, R., Manuel, A., Martiz, R., Theron, L. and Bruwer, J.P. (2015), "The Influence of "Sin Tax" on the Economic Sustainability of Small, 
Medium and Micro Liquor Store Enterprises in the Northern Suburbs of the Cape Metropolis, South Africa”, Journal of Economics, Vol. 6, No. 2, pp. 87-101.

Hammis, E. (2016), “How To Use A Blog As A Successful Marketing Tool”, Available at: http://www.business2community.com/blogging/use-blog-successfulmarketing-tool-01139310\#cetqDATwmdpZgPXH.99 (accessed June 30, 2016).

Kim, C.M. (2016), Social media campaigns: Strategies for public relations and marketing, New York, NY: Routledge.

Mavimbela, R. and Dube, E. (2016) "Can an internet adoption framework be developed for SMEs in South Africa?", Journal of entrepreneurship and innovation in emerging economies, Vol. 2, No. 2, pp. 1-16.

Mpofu, T. and Chigwende, S. (2013) "Factors influencing marketing planning and implementation in Zimbabwean SMEs", International Journal of Science: Basic and Applied Research, Vol. 12, No. 1, pp. 82-92.

Marketingdonut.com. (2016), "Your website", Available at: http://www.marketingdonut.co.uk/marketing/online-marketing/yourwebsite (accessed June 30, 2016).

National Small Business Act. (1996), “Chapter 1", Available at: https://www.thedti.gov.za/sme_development/docs/act.pdf (accessed, June 27 2016).

Nobre, H. and Silva, D. (2014), "Social network marketing strategy and SME strategy benefits", Journal of Transnational Management, Vol. 19, pp. 138-151.

Patil, D.B. and Bhakkad, D.D. (2014), Redefining Management Practices and Marketing in Modern Age, Dhule: Athrav.

Popescu, I.C., Dumitru, I., Veghes, C. and Kailani, C. (2013), "Marketing communication as a vector of the Romanian small businesses sustainable development", Amfiteatru Economic, Vol. 15, No. 7, pp. 671-686.

Pride, W.M., Hughes, R.J. and Kapoor, J.R. (2015), Foundations of business, Boston, MA, Cengage Learning.

Resnick, S.M., Cheng, R., Simpson, M. and Lourenco, F. (2016), "Marketing in SMEs: a "4Ps" self-branding model", International Journal of Entrepreneurial Behaviour and Research, Vol. 22, No. 1, pp. 155-17.

Salehi, M., Mirzaei, H., Aghaei. M. and Abyari, M. (2012), “Dissimilarity of e-marketing vs traditional marketing", International Journal of Academic Research in Business and Social Science, Vol. 2, No. 1, pp. 510-515.

Seyyedamiri, N. and Faghih, N. (2015), "Studying entrepreneurial marketing for information technology SMEs based on the classic grounded theory", QScience Connect, Vol. 1, No. 9, pp. 1-13.

Smit, Y. and Watkins, J.A. (2012), "A literature review of small and medium enterprises (SME) risk management practices in South Africa", African Journal of Business Management, Vol. 6 No. 21, pp. 6324-633. 
Taiminen, H.M.T. and Karjaluoto, H. (2015), "The usage of digital marketing channels in SMEs", Journal of Small Business and Enterprise Development, Vol. 22, No. 4, pp. 633-651.

The Banking Association of South Africa. (2016), "SME Enterprise", Available at: http://www.banking.org.za/what-we-do/sme/sme-enterprise (accessed June 27, 2016).

Van Scheers, L. (2011), "SMEs' marketing skills challenges in South Africa, African", Journal of Business Management, Vol. 5, No. 13, pp. 5048-5056.

World Bank, (2015), "Small and medium enterprises (SMEs) finance", Available at: http://www.worldbank.org/en/topic/financialsector/brief/smes-finance (accessed June 27, 2016). 